\title{
THE CONDUCT OF GRAND JURY PROCEEDINGS IN ANTITRUST CASES
}

\author{
John Henry Lewin*
}

With but few exceptions, ${ }^{1}$ all the criminal prosecutions instituted under the Sherman Antitrust Act have been commenced by grand jury indictment. This course has not been followed under constitutional compulsion; prosecutions under the Act may be instituted by information. But resort to the grand jury possesses definite advantages to the Government in its enforcement of the Sherman Act. To demonstrate this fact, brief reference must be made to the problem of proof faced by the Government in its antitrust proceedings and to the dual function of the grand jury.

A case under the Sherman Act normally entails an extensive and protracted investigation into an economic situation in which the evidence to be obtained is not only voluminous and complex but also must be sought in considerable measure in the records of those proceeded against and of others who, if not themselves defendants, are at least disinclined to cooperate in the investigation. Even after sufficient evidence has been assembled by the Department of Justice to justify prosecution in its opinion, there may yet be enough room for doubt to justify, if not to require, the question's submission to the judgment of the potential defendant's peers. Moreover, the evidence available may fall well short of that sufficient to prove guilt beyond a reasonable doubt in a criminal action, and the need for further investigation may be imperative.

The grand jury is an instrumentality for meeting both these needs. It has two primary functions: accusation and inquisition. When evidence indicating prima facie the violation of a criminal law is placed before the grand jury, it is the jury, not the prosecuting official, who takes full responsibility for determining whether the person charged should be put upon his trial. As Mr. Justice Field pointed out in an historic charge to a grand jury, "in the struggles which at times arose in" England between the powers of the king and the rights of the subject, it [the grand

* A.B., 1920, Johns Hopkins University; LL.B., r923, Harvard University. Member of the Maryland Bar. Special Assistant to the Attorney General, Antitrust Division, U. S. Department of Justice, since I935. People's Counsel, Maryland Public Service Commission, 1929-1933; Chief of Trial Section, Agricultural Adjustment Administration, U. S. Department of Agriculture, 1935.

${ }^{2}$ U. S. v. Great Western Sugar Co., 39 F. (2d) I49 (D. Neb. 1929); id., 39 F. (2d) I52 (D. Neb 1930), and eleven other cases. 
jury] often stood as a barrier against persecution in his name; until, at length, it came to be regarded as an institution by which the subject was rendered secure against oppression from unfounded prosecutions of the crown."

In a democratic nation, the need for this safeguard to the citizen has diminished. It is the inquisitorial power of the grand jury which, according to Judge Kirkpatrick in a recent case, "is the most valuable function which it possesses today and, far more than any supposed protection which it gives to the accused, justifies its survival as an institution. As an engine of discovery against organized and far-reaching crime, it has no counterpart. Policy emphatically forbids that there should be any curtailment of it except in the clearest cases."

The inquisitorial power is rendered peculiarly effective by reason of the lack of restrictions upon it. This attribute is made evident in the statement of the grand jury's powers in the leading case of Hale v. Henkel:

We deem it entirely clear that under the practice in this country, at least, the examination of witnesses need not be preceded by a presentment or indictment formally drawn up, but that the grand jury may proceed, either upon their own knowledge or upon the examination of witnesses, to inquire for themselves whether a crime cognizable by the court has been committed; that the result of their investigations may be subsequently embodied in an indictment, and that in summoning witnesses it is quite sufficient to apprise them of the names of the parties with respect to whom they will be called to testify, without indicating the nature of the charge against them. ${ }^{4}$

To the Antitrust Division, the presentation of a case to the grand jury provides an opportunity to direct the jury's powers in aid of the Division's inquiry. The handicap which the lack of subpoena power places upon preliminary investigation is at once removed. The evidence necessary for successful prosecution can be acquired, tested, and organized for presentation without the need for disclosing its nature to those against whom it is to be used. Testimony can be obtained for subsequent use, if needed, at the trial of a case for impeaching the hostile, or refreshing the forgetful, witness. If the proof fails to persuade the grand jury, this indicates that it would not persuade the petit jury, and the persons complained of may be spared the embarrassment of a criminal trial.

The importance of grand jury proceedings' to the enforcement of the Sherman Act makes it highly desirable that the law governing them be carefully observed, a caution' which is all the more consequential in view of the fact that antitrust proceedings before a grand jury may consume months of time and cost many thousands of dollars. Yet, despite the antiquity and the importance of the institution, the law relative to the grand jury, especially in federal cases, is obscure at many points and has been the subject of relatively little study. The lecture on which the present essay is based was designed to point out to the government attorney the problems he may encounter and the pitfalls he must avoid, and to consider the principal

${ }^{2}$ Charge to the Grand Jury, 2 Saw. 667,669 (C. C. D. Cal. I872).

${ }^{3}$ In re Grand Jury Proceedings, 4 F. Supp. 283,284 (E. D. Pa. 1933).

201 U. S. $43 ; 65$ (I906). 
authorities, judicial and statutory, which throw light on the course he must follow. To some extent, the original lecture form has been preserved in the discussion to follow.

The complexity of the subject matter has compelled its division into I7 sub-topics. Considerations of space have compelled their treatment with a brevity which may create the impression of a dogmatism that is by no means felt. The sub-topics to be considered are the following: (I) the use of the information as an alternative to indictment; (2) some preliminary steps; (3) summoning the grand jury and questions. as to terms of court; (4) authority to proceed; (5) qualifications and selection of grand jurors; (6) the judge's charge; (7) pleas in abatement; (8) persons who may appear before the grand jury; (9) secrecy of grand jury proceedings; (I0) privileges of the prosecuting attorney before the grand jury; (II) practical suggestions as to the prosecutor's conduct in the grand jury room; (12) subpoenas duces tefum; (13) impounding documents; (14) self-incrimination and waiver of immunity; (15) use of grand jury transcript at the trial; (I6) presentments; (I7) abuse of process.

\section{r. The Use of the Information as an Alternative to Indictment}

Although the use of the indictment is generally preferable to proceeding by information, some consideration should be given at the outset to the possible utility of that device. It is rendered constitutionally available in antitrust cases by reason of the fact that the Fifth Amendment requires that the trial of only "capital and infamous crimes" must be by indictment. By established criteria, violation of the Sherman Act is not an infamous crime: it cannot be punished by hard labor; no term in the penitentiary is specified; and since the maximum prison sentence is one year, sentence to the penitentiary cannot be imposed.

In two of the cases ${ }^{5}$ in which the Department of Justice has proceeded by an information for violation of the Sherman Act, demurrers and pleas in bar on the ground of limitations were filed to these informations and sustained. The defense also contended that a violation of the Sherman Act was an infamous crime, but that point was not pressed or decided.

A question arises whether there may be a direct appeal to the Supreme Court from a decision sustaining a demurrer to an information. It has been held in United States v. Goldman ${ }^{6}$ that the Criminal Appeals Act ${ }^{7}$ authorizes appeals from orders sustaining pleas in bar filed to informations, but the Criminal Appeals Act, in express terms, with regard to demurrers, refers only to demurrers to indictments. For that reason one might hesitate to use the information rather than the indictment, even where he has adequate evidence in his possession. An information might be utilized under the Sherman Act in cases where the Government is in a hurry-for example, where the Statute of Limitations has almost run and no time remains for a grand jury proceeding, or in cases where the Government already has ample evidence in its possession and does not need the grand jury proceedings to get more.

\footnotetext{
${ }^{\circ}$ Cited supra note $\mathrm{I}$.

' 277 U. S. 229 (1928).

' 18 U. S. C. $\$ 682$.
} 
There is a third possible situation where an information might be utilized: where an indictment returned has been quashed for some defect in the grand jury proceedings. It is conceivable that the Government, having the evidence and not wishing to repeat the grand jury process, might turn to an information. The law indicates, however, that leave of court is necessary to file an information, ${ }^{8}$ in addition to specific authority from the Attorney General. ${ }^{9}$ Perhaps leave of court might not be granted under such circumstances.

\section{e. Some Preliminary Steps}

There are certain practical steps to be taken, after it has been decided to institute grand jury proceedings. First is the selection of the jurisdiction. A guide to selection is the law announced in the Trenton Potteries ${ }^{10}$ case to the effect that, although an overt act is not necessary for the completion of a crime under the Sherman Act, criminal jurisdiction attaches in any district where the combination or conspiracy has been entered into or where any overt act has been committed by any of the conspirators in furtherance of the conspiracy. There may be a number of districts which would satisfy the rule.

If there is a choice of jurisdiction, it is advisable to confer with the district attorney in the prospective district and, if possible, with the judge, to see whether there are any objections to proceeding there. Above all things, examine all the general statutes relating to grand juries, including applicable state law. ${ }^{11}$ One should, of course, see that the law has been followed strictly by the Clerk of the Court and by the Jury Commissioner in the district. ${ }^{12}$

In timing the beginning of the proceedings these considerations must be kept in mind: first, the lawyer's needs for preparation; second, the time that is required for the issuance of subpoenas and subpoenas duces tecum. A reasonable time for compliance with these orders must be afforded, along with the procedural time limitations contained in the various statutes.

Another suggestion is to examine pleas in abatement that have been interposed to other indictments in that district, because they will be likely to expose the kind of defects or alleged defects that may be present in the procedure followed in that district. Although the plea in abatement is not a very serious obstacle, since rulings on it go to matters of substance only and are not appealable, nevertheless it is desirable to avoid the dilatory effect of such pleas, however formal or slight their ground. If a defect creeps into the proceedings, notwithstanding all efforts to avoid

${ }^{8}$ Albrecht v. U. S., 273 U. S. I (Ig26). $\quad$ U. S. v. Cohen, 273 Fed. 620 (D. Mass. I92I).

${ }^{10}$ U. S. v. Trenton Potteries, 273 U. S. 392 (1927).

${ }^{21}$ In the District of Columbia the specific provisions of the District Code should be examined, bearing in mind that some of those provisions may override provisions of the general law applicable to other districts. One must not be dogmatic about that because in some matters the situation may be reversed. As a practical matter, it may be possible to satisfy both the general statutes and the local code, and in this way make assurance doubly sure.

${ }^{12}$ It would be worth while to cross-examine the Clerk and Jury Commissioner very fully. If there are defects in the way in which the jury box, or the panel, or the grand jury itself, has been composed, it is advisable to request the drawing of a new grand jury. 
defects, it may be wise to obtain another indictment from another grand jury, in the constitution of which that defect has been completely eliminated. Or consideration might be given to the earlier suggestion that the prosecution be shifted to one initiated by information.

\section{Summoning the Grand Jury; Questions as to Terms of Court}

The federal statute ${ }^{13}$ providing for the summoning of grand juries reads as follows:

No grand jury shall be summoned to attend any district court unless the judge thereof, in his own discretion or upon a notification by the district attorney that such jury will be needed, orders a venire to issue therefor. If the United States Attorney for any' district which has a city or borough containing at least 300,000 inhabitants shall certify in writing to the district judge, or the senior circuit judge of the district, that the exigencies of the public service require it the judge may, in his discretion also order a venire to issue for a second grand jury....

The important thing about the statute to remember is that the issuance of the venire facias is a condition precedent. ${ }^{14}$ In alleging in the certificate from the District Attorney that the exigencies of the public service require an additional or special grand jury, it may be better practice to explain in allegations more detailed than the terms of the statute what exigencies exist.

The law relating to the duration of terms of court must be considered in connection with summoning the grand jury. A grand jury proceeding has been held to be a "cause" within the meaning of the United States statute that provides:15

When the trial or hearing of any cause, civil or criminal, in a district court has been commenced ... it shall not be stayed or discontinued by the arrival of the time fixed by law for another session of said court; but the court may proceed therein . . . with the same effect as if another stated term of the court had not intervened.

Another statute provides in part $^{\mathbf{1 6}}$ that a district judge may, upon request of the district attorney or of the grand jury or on his own motion, by order authorize any grand jury to continue to sit during the term succeeding the term at which such request is made, solely to finish investigations begun but not finished by such grand jury, but no grand jury shall be permitted to sit in all during more than three terms. Nevertheless, it may be very important to ascertain exactly when the term begins and when it ends, because if the grand jury starts into an investigation after the term for which it has been impaneled, its later action is ultra vires. ${ }^{17}$

\footnotetext{
Is 28 U. S. C. $\$ 421$. See also 28 U. S. C. $\$ 416$ for the method by which writs of venire facias shall issue when directed by the court.

The District of Columbia Code, $\$ 348$, has specific provisions relating to impaneling an additional grand jury in the District.

16 Clawson v. U. S., r14 U. S. 477 (1885).

${ }^{15} 28$ U. S. C. §I2; U. S. v. Rockefeller, 22 I Fed. 462 (S. D. N. Y. I914).

1628 U. S. C. $\$ 42 \mathrm{I}$.

${ }^{12}$ Bronson v. Schulten, 104 U. S. 4 10 (I88I); Marion Steam Shovel Co. v. Recves, 76 F. (2d) 462 (C. C. A. 8th, 1935); U. S. v. Louisville \& N. R. Co., I77 Fed. 780 (W. D. Ky. 1910).

The problem was presented in a recent antitrust case. After a new term at another place in the district had begun, and after some question might have been raised whether the term in which the investigation started had expired, the grand jury returned an indictment for perjury against one of the wit-
} 
In a number of districts it is provided that the judge shall hold court at various places therein, thus creating a series of terms throughout the year held at different places. The question is presented, in the absence of express language in the statute or rule, whether a term begining at one place in the district ends when the next term at a different place begins, or whether the first term continues until the beginning of the next term at the first place. Practice in the various districts and such decisions as there are indicate clearly that the latter rule is almost uniformly applied. ${ }^{18}$ The possible exception is the District of Connecticut, ${ }^{19}$ although a later case in that district seems to return to the majority rule.

\section{Aithority to Proceed}

The Sherman Act, in Section 4 relating to civil cases, provides that civil cases be conducted by the several district attorneys of the United States in their respective districts "under the direction of the Attorney General." There is no similar provision in the Sherman Act relating to criminal proceedings, but there is a statute, and an important one, on which the authority of the special assistants to the Attorney General is based. It provides:

The Attorney General or any officer of the Department of Justice, or any attorney or counselor specially appointed by the Attorney General under any provision of law, may, when thereunto specifically directed by the Attorney General, conduct any kind of legal proceeding, civil or criminal, including grand jury proceedings and proceedings before committing magistrates, which district attorneys may be by law authorized to conduct, whether or not he or they be residents of the district to which such proceeding is brought. ${ }^{20}$

Now, since district attorneys are required by another statute ${ }^{21}$ to perform the general duty of prosecuting all criminal offenses against the United States, the statute just quoted, when complied with, gives the special assistants to the Attorney General broad powers. Important words in the statute are "specifically directed." In letters of authority it is usual to refer in some general terms to the subject matter upon which the special assistant is specifically directed to proceed.

Another important word in the statute is "conduct." The usual letters of authority first authorize the special assistants "to assist" in grand jury proceedings, and then relate the authority to "conduct" to the authority to assist. It is more important to have authority to conduct the prosecution as a whole than to have authority to assist in the conduct of the grand jury proceedings. Furthermore, the letter of authority should not be limited to conducting grand jury proceedings. Possibly such limited authority would not even justify the signing of an indictment or taking the

nesses. If the original term had expired that indictment might have been bad, because it was not continued business. If the term continued, the indictment was clearly good.

${ }^{18}$ Florida v. Charlotte Harbor Phosphate Co., 70 Fed. $883,884-885$ (C. C. A. 5th, r895); Denver Livestock Commission Co. v. Lee, I8 F. (2d) II, I3 (C. C. A. 8th, I927); Petition of Thames Towboat Co., 23 F. (2d) 493,495 (D. Conn. 1927).

${ }^{30}$ Loewe v. Union Savings Bank, 222 Fed. 342 (D. Conn. 1915). Cf. Petition of Thames Tugboat Co., supra note $\mathrm{I} 8$.

${ }_{30} 5$ U. S. C. $\S_{310}$ 
preliminary steps in the trial. One decided case holds that it is the best practice for the letter of authority to be filed with the Clerk of Court. ${ }^{22}$ That makes it all the more important that the letter be carefully phrased and that the authority attempted to be exercised falls within its terms.

\section{Qualifications and Selection of Grand Jurors}

On the qualifications of grand jurors in the federal districts outside the District of Columbia it will be important to study the rules obtaining in the state where the district court sits, because the federal statute provides: ${ }^{23}$

Jurors to serve in the courts of the United States, in each State respectively, shall have the same qualifications, subject to the provisions hereinafter contained, and be entitled to the same exemptions, as jurors of the highest court of law in such State may have and be entitled to at the time when such jurors for service in the courts of the United States are summoned.

Such qualifications and exemptions may be based upon age, citizenship and occupation.

To draw the panel for a grand jury the federal law designates the Clerk of the Court and a Jury Commissioner, a standing Jury Commissioner of the Court, who must belong to the opposite political party from that to which the Clerk belongs. They must obtain the names of qualified prospective jurors in some impartial way and act together in placing these names in the jury box. They draw the panel on order of court, drawing names alternately. First the Jury Commissioner draws and then the Clerk draws, and so on. Although all such requirements are detailed in the federal statute ${ }^{24}$ some are probably frequently disregarded in practice, a tendency that an attorney assigned to conduct grand jury proceedings must be very careful to guard against.

From the twenty-three ${ }^{25}$ persons summoned and accepted as grand jurors the court appoints a foreman, who is given the power to administer oaths and affirmations to witnesses. ${ }^{26}$ The court also designates a secretary of the grand jury, whose duty it is to keep certain minutes of the proceedings-not a transcript of the testimony, but minutes of attendance of jurors, the number and names of witnesses, and, more particularly, the way in which the jurors in their own secret deliberations vote upon a presentment or an indictment.

There seems to be little law on the question of the right to challenge grand jurors. It is reasonably clear that there may be a challenge to the whole array, because of some substantial defect in the way in which the grand jury has been drawn. Here, since the federal statute dealing with challenges relates only to petit jurors, ${ }^{27}$ the rule of the common law is followed, although in early federal cases the law of the state where the federal court was sitting was generally applied to such matters. ${ }^{28}$

${ }^{22}$ May v. U. S., 236 Fed. 495 (C. C. A. 8th, r916).

${ }^{23} 28$ U. S. C. $\$ 411$.

${ }^{24} I d . \$ 412$. ${ }^{25} I d$. $\$ 420$.

${ }^{28}$ U. S. v. Eagen, 30 Fed. 608 (C. C. E. D. Mo. I887); U. S. v. Reed, Fed. Cas. No. I6,134 (C. C. N. D. N. Y. 1852); U. S. v. Devlin, Fed. Cas. No. 14,953 (C. C. E. D. N. Y. 1868). 
An old federal case apparently holds that grand jurors may be challenged for cause by any person to be affected by their findings, and that the right of challenge may be exercised even by one who, though at large, has been warned he may be made a defendant. ${ }^{29}$ This decision seems questionable, because it is difficult to see on what ground the law could give such a person a standing in court to enter a challenge. The terms of another federal statute clearly imply that some right of challenge exists with regard to grand jurors. ${ }^{30}$ Since the Government would certainly have a standing in the proceedings, it is reasonable to suppose that the right of challenge referred to in that statute relates to the right of the Government only. The Government may therefore have individual challenges for cause (but probably no peremptory challenges) and challenges to the whole array for cause.

\section{The Judge's Charge}

When the jury has been properly drawn and selected, and challenges exercised or waived, the time has come in the ordinary course for the judge to charge the grand jury. This charge is usually in general terms and concerns itself to a large extent with the mere mechanics of grand jury service. For example, the judge will undoubtedly charge something with regard to the burden of proof. He will ordinarily indicate that the grand jury need not find a crime has been committed beyond a reasonable doubt, but merely that there is probable cause to believe a violation of the law has been committed. He will point out that the foreman will have general charge over the jurors and that the special assistants to the Attorney General or the district attorney will be present to assist them in the conduct of their investigation and in bringing evidence before them, and in advising them with regard to the law. He will also, no doubt, include instructions to avoid permitting anyone to approach them, and comment on the character of the rule of secrecy. Chief Justice Marshall, in the famous trial of Aaron Burr, ${ }^{31}$ denied a motion to charge the grand jury more specifically as to the applicable law, placing his ruling on the ground that "it would be manifestly improper to commit the opinion of the Court on points which might come before them, to be decided on the trial in chief." Chief Justice Taney in another case ${ }^{32}$ charged the grand jury: “. . . in all cases demanding more precise and particular knowledge, you will have the aid of the district attorney whose duty it is to counsel you in matters of law, whensoever you may think proper to require it."

The last quotation tends to indicate that counsel should have a request from the grand jury itself before volunteering detailed advice on controversial questions of law.

\section{Pleas in Abatement}

It was suggested above that it is advisable to study any pleas in abatement that had been filed in other cases in the district for information as to the character of

${ }^{20}$ U. S. v. Blodgett, Fed. Cas. No. 18,312 (C. S. D. Ga. 1867 ).

${ }^{80} 28$ U. S. C. \$4rg.

s1 BuRR's Truals (Robertson's ed., I808) I74.

${ }^{82}$ Charge to Grand Jury, Fed. Cas. No. 18,257 (C. C. D. Md. 1836 ). 
defects that may be prevalent or usual in that district. The federal statute ${ }^{33}$ provides in part:

No plea to abate nor motion to quash any indictment upon the ground of irregularity in the drawing or impanelling of the grand jury or upon the ground of disqualification of a grand juror shall be sustained or granted unless such plea or motion shall have been filed before, or within ten days after, the defendant filing such plea or motion is presented for arraignment.

To take advantage of that statute, in the absence of a stipulation with counsel for the defendants, it is good practice after the indictment is returned tỏ apply for a formal day of arraignment as early as possible, because this ten-day period of limitation runs only from the arraignment. Another interesting provision of that statute states that even an indictment which is defective in the respects that the statute indicates, tolls the running of the statute of limitations. It is further provided: $:^{34}$

No plea to abate nor motion to quash any indictment, upon the ground that one or more unqualified persons served upon the grand jury finding such indictment, shall be sustained if it appears that twelve or more jurors, after deducting the number so disqualified, concurred in the finding of said indictment: Provided, however, That no juror shall be permitted to testify, in this connection, as to whether he or any other individual juror voted for or against the finding of such indictment....

The number of the grand jurors is twenty-three; a quorum is sixteen, and the vote of twelve qualified jurors is necessary in order to return a true bill. If sixteen jurors are present they are sufficient to continue with the proceeding. ${ }^{35}$ Of course, it is much more advisable to have all jurors present, and as a practical matter counsel and the foreman should join in trying to enforce a rule that limits very materially the right of jurors to be absent. This is important to avoid such a situation as an indictment for which only twelve qualified jurors voted, one of whom has been absent from the grand jury room for an appreciable amount of time. If those facts were ever to come to light, the contention could be made with plausibility that the juror who was absent most of the time really did not exercise his own discretion on the evidence in casting his vote. Hence, the wisest course is to have just as many of the twenty-three jurors present as possible.

\section{Persons Who May Appear Before the Grand Jury}

For many years only district attorneys and attorneys specifically authorized could appear before the grand jury. It was held that they could make their own notes, even, it has been decided, ${ }^{36}$ in shorthand. It was not proper, however, to have before

${ }^{83}$ 18 U. S. C. $\$ 556 a$.

s4 18 U. S. C.- $\$ 554$ a. It should be noted in this connection that 28 U. S. C. $\$ 879$ provides that there shall be no reversal in the Supreme Court or in a Circuit Court of Appeals, upon a writ of error, for error in ruling upon a plea in abatement made on such a ground.

${ }^{85} 28$ U. S. C. $\$ 419$.

${ }^{30}$ U. S. v. Haskell, 169 Fed. 449 (E. D. Okla. 1909). Cf. U. S. v. Philadelphia \& R. Ry. Co., 22I Fed 683 (E. D. Pa. 1915). 
the grand jury a stenographer to assist counsel..$^{37}$ That serious defect was rectified by a I933 amiendment specifically providing that a stenographer to assist Government counsel may be present. ${ }^{38}$

The amended statute provides: $:^{39}$

No indictment found and presented by a grand jury in any district or other court of the United States shall be deemed insufficient, ... by reason of the attendance before the grand jury during the taking of testimony of one or more clerks or stenographers employed in a clerical capacity to assist the district attorney or other counsel for the Government who shall, in that connection, be deemed to be persons acting for and on behalf of the United States in an official capacity and function.

That would seem to indicate that the transcript now taken by this official stenographer ${ }^{40}$ is the property of the Government. It is a transcript taken by an official employee of the Department of Justice, and the function of the stenographer in taking the transcript is especially "to assist" counsel for the United States. Therefore, it is to be exposed or disclosed only upon the authority of the Attorney General, as is the case with all other documents belonging to the Department of Justice.

\section{Secrecy of Grand Jury Proceedings}

Generally speaking, grand jury proceedings are confidential. A number of reasons have been advanced for this principle. One, to prevent the escape of the accused. Two, to insure free and untrammeled deliberations. Three, to encourage fearless action. Four, to prevent interference or tampering with witnesses. ${ }^{41}$ Five, to prevent opportunities for perjury at the trial, if evidence against the accused is fully exposed. Six, to protect witnesses so as to encourage them to appear, to make complaints, and to testify fully. Seven, to protect the good names of innocent persons not indicted. Eight, to reinforce the rule that juries should not impeach their own verdicts.

There is, moreover, no need for disclosure. The grand jury can be relied upon to do its duty and to protect the citizen without having its deliberations open to scrutiny. The indictment is merely a charge, not a conviction, and the accused can be amply protected at the trial. In cases like violations of the Sherman Act, the proceedings, as indicated, ${ }^{42}$ could well be by information rather than by any indictment at all.

${ }^{37}$ Latham v. U. S., 226 Fed. 420 (C. C. A. 5th, r915); U. S. v. Rubin, 218 Fed. 245 (D. Conn. I914). Cf. U. S. v. Rockefeller, 22I Fed. 462 (S. D. N. Y. 1914).

${ }_{38} 8$ U. S. C. $\$ 556$.

"To comply with the statute such stenographer must be "employed in a clerical capacity to assist" Government counsel. In Gargotta v. U. S., 77 F. (2d) 977 (C. C. A. 8th, I935) a "contract stenographer," who had taken an oath of secrecy, was regarded as complying with the statute. See also U. S. v. Weathers, 21 F. Supp. 763 (N. D. Ga. x937). If a "contract stenographer" is not used, then a specific appointment employing the stenographer in a clerical capacity to assist Government counsel should be obtained from the Attorney General and such stenographer should, preferably, take the oath prescribed for all federal officials.

"This reason must apply only to the witnesses before the grand jury, because after the indictment is returned, the accused is entitled to have a list of the witnesses who will appear against him at the trial.

${ }^{2}$ See p. Ir4, supra. 
The reasons for the principle of secrecy do not apply with equal force to all persons or to all types of data. It becomes necessary, therefore, to make certain distinctions. To what extent is disclosure prohibited or privileged to these persons: (I) grand jurors; (2) court officials present before the grand jury, including the prosecutor; (3) witnesses? To what extent is disclosure forbidden as to these subject matters: (I) the vote on the indictment; (2) the formal minutes kept by the secretary; (3) the transcript of the testimony?

With regard to the grand jurors it seems that all the reasons that have been enumerated apply. Although at the very early common law there was no obligation of secrecy resting on a grand juror, by 1600 at least it was the rule under the common law that grand jurors were not to disclose their proceedings, and they were actually put under an oath of secrecy. ${ }^{43}$ The oath taken from the Book of Oaths ${ }^{44}$ in its quaint language reads as follows:

The Oath of the Great Inquest.

Ye Shall truly enquire and due presentment make of all such things as you are charged withall, on the Queen's behalf, the Queen's council, your own, and your fellows, you shall well and truly keep; and in all other things the truth present. So help you God, and by the contents of this Book.

Here then is a clear obligation upon the grand jurors not to disclose testimony at least for a certain time. It is also usual in the judge's charge to the grand jury to stress the presence of this obligation. The following from a charge of Mr. Justice Field ${ }^{45}$ is typical:

You are also to keep your own deliberations secret; you are not at liberty even to state that you have had a matter under consideration. Great injustice and injury might be done to the good name and standing of a citizen if it were known that there had ever been before you for deliberation the question of his guilt or innocence of a public offense. You will allow no one to question you as to your own action or the action of your associates on the grand jury.

In addition to this obligation resting on the grand jury not to disclose, there also seems to be indicated in the books a privilege accorded to the grand jurors not to disclose, even when released from the obligation. That privilege seems to rest on the idea that the state should accord the privilege to remain silent in return for fearless action by the grand juror. Of course, as a privilege, it can be waived as can other privileges, but it has been suggested that this privilege is not the privilege of the individual grand juror but the privilege of the entire grand jury which alone can waive it. ${ }^{46}$

Both obligation and privilege against disclosure cease when terminated by the court upon a finding that the ends of justice so require. According to one decision, ${ }^{47}$ in every such case the court is called upon to balance two policies, the one requiring

\footnotetext{
${ }^{8}$ Lambard, Eirenardia (1588) 397.

"Boor of OAths (1688 ed.) x13-ז×5.

${ }^{46}$ Charge to the Grand Jury, 2 Saw. 667,677 (C. C. D. Cal. 1872).

${ }^{46} \mathrm{See}$, on this subject generally, 5 Wigmore, Evidence (2d ed. I923) \$\$2360-2464.

${ }^{47}$ In re Grand Jury Proceedings, supra note 3.
} 
secrecy for the reasons given above, and the other calling for disclosure for the considerations relied on by the moving party. The court apparently may exercise this discretion even before the indictment is returned and the accused arrested, but, after the indictment and arrest, there is a well-defined opinion that a number of the reasons for secrecy either have disappeared or have lost much of their importance. ${ }^{48}$ There are objections to this line of reasoning, but it seems rather well established. According to some authorities the obligation seems to some extent to cease automatically. ${ }^{49}$ According to others, the court must exercise its discretion, weighing both considerations. ${ }^{\text {io }}$ It is certainly difficult to see how the reasons for secrecy resting on encouragement of fearless action, prevention of tampering with witnesses, or protection against perjury at the trial, could possibly disappear by the mere returning of an indictment.

There are many reasons for secrecy of the grand jury proceedings which operate logically even after the indictment is returned and these have been influential in some cases. Thus, Judge Stone in the Madison oil cases was unwilling to release the obligation he had imposed on the witnesses, even to permit the defendants to prepare their case for trial, and even though the Government was willing to consent to the release of the oath. $A$ fortiori he would have enforced a continuation of the oath on the grand jurors. Judge Proctor, in the American Medical Association case, ${ }^{51}$ charged the grand jury that the obligation should continue until released by court order. And in that case, after the indictment was returned, the defendants applied for permission to have the ex-grand jurors interrogated and the transcript examined either by the court or defendant's counsel. This was for the avowed purpose of ascertaining whether the Government counsel advised the grand jury as to the law, argued the facts to persuade it to return an indictment, and laid incompetent evidence before it. One of the defense counsel filed a supporting affidavit in which he alleged that he had been informed by various unnamed persons, and therefore believed, that the attorneys for the Government engaged in the conduct described above. The Government filed a counter motion to strike defendant's motion. In granting this counter motion, Judge Proctor, after first stating that he could have taken a purely legalistic view and have ruled that no justiciable question was presented, said:

Accordingly, for all those concerned who may wish my views, I feel constrained to say that in my opinion the oath taken by, the grand jurors "to keep secret the counsel of the United States, your fellows and your own" is not limited by time or circumstances. It is a lasting obligation binding all who have served as grand jurors. . . . Neither indictment, arrest of the accused, nor expiration of the jury term will operate to release a juror from the oath of secrecy, as the defendants here contend. That can only be done by a court acting in a given case when in its judgment the ends of justice so require. . . . In keeping with custom, instructions to this effect were given the former grand jurors and they were

${ }^{48}$ Metzler v. U. S., 64 F. (2d) 203,206 (C. C. A. 9th, I933).

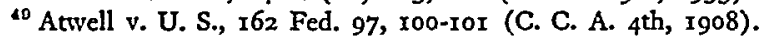

${ }^{10}$ Latham v. U. S., 226 Fed. 420,421 (C. C. A. 5th, 1915); Fotheringham v. Adams Express Co., 34 Fed. 646,648 (C. C. E. D. Mo. 1888); U. S. v. Amazon Industrial Chem. Corp., 55 F. (2d) 254, 261-264 (D. Md. I93I).

t1 U. S. v. Am. Medical Ass'n, 26 F. Supp. 429 (D. C. 1939). Judge Proctor expressly refused to follow the Atwell case, supra note 49. 
admonished to strictly observe the same. I am confident those instructions conform to the ancient and traditional concept of a grand juror's obligation. ${ }^{52}$

The-last part of Judge Proctor's opinion bears on the question what showing should move the court to remit the oath or the obligation of secrecy on the ground that the ends of justice so require. Judge Proctor says:

As to the second proposition, there is no question of a court's power to go back of an indictment to inquire whether vitiating irregularities induced the finding. ... But it is a power sparingly used; justified only where by proper verified pleading a clear and positive showing is made of gross and prejudicial irregularity influencing the grand jury in returning an indictment. Averments on information and belief have been uniformly held not enough. ... That is conceded by defendants. They admit a pleading to abate or quash must be certain and definite in its allegations of prejudicial facts. They assert as a reason for asking an investigation by the court that they are unable to make the fequisite averments and oath. Thus we have the novel situation of defendants admitting that they are in no position to file the essential pleading to justify the court in making an inquiry, yet nevertheless asking that the inquiry be ordered anyway, in the expectation or hope that material will turn up to support a proper plea. Manifestly the court ought not grant such a motion. ... The effect of granting such a motion would be to break down all legal checks against technical, dilatory tactics. The strong presumption of the regularity of grand jury proceedings would no longer prevail. . . .53

Even when the obligation is released it may be released only partially. Strong reasons exist for not exposing facts tending to impeach the finding, especially the facts surrounding the vote or how the.individual jurors voted. The latter seem peculiarly sacrosanct.

At the common law grand jury witnesses, unlike jurors, were not under an obligation of secrecy. This is illustrated by the form of their oath, ${ }^{54}$ which omits any oath of secrecy. Nevertheless, by analogy, most of the reasons recited above in favor of secrecy for grand jurors probably apply equally to witnesses. Indeed, there has been developed in a number of districts the practice of imposing an oath of secrecy upon witnesses. The authority for the practice may rest upon a modification of the early common law, ${ }^{55}$ or it may rest upon the power of the district courts to make rules of general application, or even rules of this character in particular cases. Even where this obligation is imposed, it of course does not sequester the facts known to the witness, but merely prevents him from revealing what transpired in the grand jury room.

It would seem clear from the authorities that the witnesses also have a privilege against revelation of their testimony, and that they can insist on this privilege as against disclosure (a) by grand jurors, (b) by themselves under compulsion, or (c) by officers of the court. Here again the obligation, if imposed, or the privilege, will

${ }^{52} I d$. at 430 .

${ }^{84}$ Book of OATHS (1688 ed.) 113-115.

si Id. at 430 .

${ }^{85}$ The Supreme Court's willingness to recognize a "growing" common law when common law governs rulings on the adjective side of criminal law is illustrated by Funk v. U. S., 290 U. S. 37X (1933). 
cease when the ends of justice require it, upon direction by the court based on a finding of that fact. ${ }^{56}$

The vote on the indictment should remain absolutely secret at all times, except to the court. A federal statute ${ }^{57}$ provides in express terms: "No juror shall be permitted to testify . . . as to whether he or any other individual juror voted for or against the finding of such indictment," and any inquiries addressed to grand jurors or to witnesses, not avowedly for the purpose of eliciting this information yet having the tendency to do so, ought to fall by the same token.

In regard to the minutes kept by the secretary, it has been the custom, and the same statute provides, that these records shall not be made public except on order of the court. The secretary is required to file the minutes with the Clerk when the indictment is returned. When asked to permit the exposure of the grand jury minutes, Judge Learned Hand has said $:^{58}$

It is said to lie in discretion, and perhaps it does, but no judge of this court has ever granted it, and I hope none ever will.

There are many cases where inspection of the grand jury minutes has been refused. ${ }^{58}$

The transcript of the testimony may be kept secret for the same reasons enumerated above. In addition it may be entitled to secrecy as Government property. The statute ${ }^{60}$ that permits the presence of a stenographer in the grand jury room provides that the stenographer is to assist counsel for the Government. Since he is thus acting in an official capacity, any transcript which he transcribes is certainly the property of the United States and should be revealed only when authorized. by the Attorney General.

\section{Privileges of the Prosecuting Attorney before the Grand Jury}

In United States $v$. Rintelen, ${ }^{61}$ one of the grounds set forth in a plea in abatement interposed to an indictment for criminal conspiracy was as follows: The district attorney or his assistant (a) expressed to the grand jury opinions on the questions of law and fact involved, (b) asked that an indictment be found, (c) handed the grand jurors a list of the proposed defendants; and (d) the grand jury found an indictment without a discussion of the evidence and without changing the names on the list. The proof in support of that plea was obtained from evidence taken before a subcommittee of the House of Representatives engaged in an investigation of the office of the district attorney. At this investigation a number of grand jurors had testified that the district attorney had placed the evidence before them, summed it up, and charged them as to the law.

District Judge Augustus N. Hand granted a motion to strike the plea in abate-

${ }^{60}$ See 5 Wigmore, loc. cit. supra note 46.

${ }^{88}$ U. S. v. Garsson, 29x Fed. 646, 649 (S. D. N. Y. 1923).

${ }^{20}$ See, e.g., U. S. v. Rintelen, 235 Fed. 787,789 (S. D. N. Y. 1916); U. S. v. Goldman, 28 F. (2d) 424, 43 I (D. Conn. 1928); U. S. v. Oley, 21 F. Supp. 28 I (E. D. N. Y. 1937).

${ }^{\circ 0} \mathrm{I} 8$ U. S. C. $\$ 556$.

${ }^{61} 235$ Fed. 787 (S. D. N. Y. I916). 
ment, holding it insufficient in law. Upon the question of conduct of counsel in the grañd jury room, he said:

It will hardly be contended, I think, that the district attorney, or his assistant, exhibited any passion at the sessions of the grand jury, and I cannot perceive the slightest ground for believing that either of them in any way attempted to dominate or control that body in the finding of the indictment. Without regard to the questions of legality, which I shall presently discuss, all that was done was a presentation of the case in a perfectly temperate way by these prosecuting officers. As a matter of fairness and decorum, there can be no question that these men met every obligation. The only matters for discussion are whether they exceeded their rights in reading the law, reading some of the minutes at the request of the grand jurors, summarizing the evidence, asking for the indictment, and giving to the grand jury a list of the defendants. ${ }^{62}$

Judge Hand went on to say that the district attorney or his assistant is intended to be present, and then he said:

If he does not give the grand jurors the statute, they will usually not know what the investigation is for. If in a complicated case he were not allowed to show the grand jurors the bearing of the evidence upon the alleged violation of the statute, they would certainly be confused as to the entire situation. Even a trained judge is often unable to understand the bearing of relevant testimony without the aid of counsel. Asking the grand jury to find an indictment is but putting in words what every act of the government, and its representatives, means and is well known to mean. What reasonable objection can be urged against allowing the man who has prepared the case to refresh the recollection of the grand jurors by summarizing the evidence taken, perhaps, over weeks or months, and reading from the minutes and giving them a list of the names of the persons charged with the crime? Any objection is really, if not ostensibly, based on the supposition that grand juries are devoid of all independence and prosecuting officers are either tyrannical or dishonest. ${ }^{63}$

Then, to show the kind of conduct that would be regarded as being improper conduct, Judge Hand turned to the case of United States v. Wells, ${ }^{04}$ and said of it:

... the district attorney not only gave the grand jury a list of the defendants and commented on the weight of the evidence, but before the indictment was signed was requested to leave the room by one of the jurors, so that there could be discussion, and refused to go, said that no discussion could be had until the indictment was signed, directed the foreman to sign the indictment without permitting further consideration or reading of the indictment, and withheld various documents from the inspection of the grand jury, the contents of which they were obliged to take from the statements of the district attorney only. It is manifest that the facts of that case were utterly different from those of the case at bar. The indictment there was evidently controlled by the district attorney, was not the finding of the grand jury, and consequently the plea in abatement was there properly sustained..$^{\circ 5}$

From these statements one can discern the kind of thing that constitutes improper conduct before grand juries. Grand jurors must be neither dominated nor controlled. At the same time they should be and must be assisted, and any conduct merely going that far is perfectly proper conduct. As a matter of practice, counsel

\footnotetext{
${ }^{02} 1 d$. at $79 \mathrm{r}$.

" 163 Fed. 313 (D. Idaho, 1908).

os Id. at 79r.

${ }^{85}$ U. S. v. Rintelen, 235 Fed. at 792.
} 
does-and should-absent himself from the room after he has submitted the evidence and done what moderate summing up is necessary. No one should be present at the final deliberations except the jury itself. No one should know how each juror voted except the court, when the fact is properly revealed to it.

\section{Practical Suggestions as to the Prosecutor's Conduct in the Grand Jury Room .}

In the light of the foregoing principles, which outline very clearly the rules that should govern one's attitude and actions before the grand jury, a few practical suggestions are offered:

In the first place, the usual grand jury, or at least most of the grand jurors, are probably inexperienced, nervous and ill at ease. Very few of them will have ever served on any grand jury or any jury before. It is important, in view of this fact, for counsel to adopt a fairly confident attitude. He must feel his way along, but certainly his demeanor, if possible, should inspire confidence.

$\mathrm{He}$ is entitled to make and should make an opening statement, a restrained opening statement. In it he should first introduce himself and his colleagues. He ought to give the grand jury an idea how onerous but how interesting the task is going to be and indicate with the utmost courtesy that he has their convenience and comfort under consideration. The opening statement should not be argumentative. A brief general outline of the law which may be applicable and of the facts should be given. There must be stressed the need of full attendance, the requirement of a quorum of sixteen, the obligations of secrecy, the relations with the press reporters who, if it is an important case, will be buzzing like flies outside the grand jury room. Warn the jurors against outside influences. State that you are there to help them get the facts and to assist them if they have any questions with regard to the law. When they ask any questions-and they will do so after they get their nerve upmeet them more than half way and try to give them a full and complete explanation even though the answer seems obvious.

In a complicated case the evidence may be opened with what is sometimes called a "prologue," to sketch in for the grand jury by testimony some background upon which they can superimpose the facts relating to the specific case before them. It will also enable them to understand those specific facts. This may be done by calling friendly expert witnesses to present this background. It is better to put them on at the very' beginning of the grand jury proceedings, because after a while the grand jury is going to become restive and bored and will long for an end to the proceedings, so any use of background material then would seem an anticlimax.

Appear to make speed. It is important to make speed, but, while doing so, it is also important to appear to make speed. A grand jury might well resent any indication that counsel is dragging the proceedings out. Postpone hostile witnesses, if any are to be called, until the affirmative facts establishing the case have been presented. If it is a long session counsel should, if possible, suggest a recess. It affords a change of work, permits him to check up, to revamp his plans, and to prepare 
perhaps a tentative draft of the indictment; it gives the jurors a rest and a chance to attend to their private affairs.

It is not necessary that all the proof be established to the same extent as is required in the trial of the case. Yet the grand jury proceeding gives counsel an opportunity for a "dress rehearsal." Of course, documents competently proved and authenticated are much more desirable in any inquest than documents not so proved. Therefore, although the Government is entitled to put in documents furnished in response to a subpoena duces tecum without authenticating them further, here is a good opportunity to have them authenticated and to call witnesses who can prove the signatures before the papers are offered in evidence. If there is a large quantity of documents, do not do as the unfortunate district attorney in the Wells case did, prohibit the jury from examining them. On the other hand, don't do the foolish thing of insisting that the grand jury hear you read every document produced, relevant or irrelevant. Between those extremes the following technique is recommended: Select the documents that you think most relevant. Be fair. Don't suppress any which slant against your thesis. But in the main present only the documents most relevant to the issue. Read those to the jury or have them read. Have the rest of the documents made available and make it perfectly clear to the grand jury, not once, but several times, that the documents are there for their inspection. Sometimes they will inspect them; sometimes they will call for the documents and read them. Sometimes, of course, they won't need that much evidence to become convinced.

Hostile witnesses must be called if asked for by the grand jury, but even without such a request it may still be desirable to call them. What are the purposes for doing so? First, to get the facts supporting the indictment out of the mouths of hostile witnesses. That may be the only real source open, and it may be necessary to get these affirmative facts from those witnesses to use in the trial. Second, to obtain admissions in case the companies with which the witnesses are connected are indicted, or confessions if they knowingly waive immunity and are themselves to be defendants to the indictment. And third, even though the Government has sufficient facts in its possession to feel sure of getting an indictment, it is always desirable to know something about the character of the defense in order to prepare best for trial. There is no better way to find out what the defense is likely to be than to summon a representative number of hostile witnesses.

If hostile witnesses are to be examined, it is usually necessary to ask them leading questions, sometimes long involved questions, and, perhaps, to make assumption upon assumption before getting the proper answer. It may be necessary to return to the subject over and over again until finally the perjuring or evasive witness breaks down and tells the truth. When he does so it will usually be in a short answer, yes or no, to an involved question. When counsel undertakes to use that transcript in the trial of the case, objections may be raised. One objection that appealed strongly to the trial judge in the Madison oil cases was that the questions 
were leading questions. He seemed to feel it improper at the trial to refresh the recollection of the witnesses by giving them from the transcript their answers to leading questions.

There is probably a way of eliminating that objection, if it recurs. After a hostile, evasive witness has finally told the truth by answers to leading questions, counsel may then retrace his steps very briefly and ask the witness in non-leading questions for the same sort of information, letting the witness phrase the answers. He may then be in a frame of mind to answer non-leading questions very freely. Another suggestion is that a fair summary of his final testimony before the grand jury be prepared for his signature. Signing would, of course, have to be voluntary. No authorities have been discovered dealing with such practice.

\section{I2. Subpoenas Duces Tecum}

Since grand juries exercise a power that is to some extent autonomous and in the nature of judicial process,.subpoenas duces tecum may be used for the production of documents before them, even though there is no formal complaint or charge of violation of law. Here the grand jury differs radically from the administrative or quasi-legislative bodies, as to which due process requires that a charge must be laid before the power to subpoena may be exercised. Grand juries may go on "fishing expeditions." Nevertheless, there seems to be a requirement that some showing be made of possible relevancy and materiality to the subject matters of the grand jury's deliberations.

Persons summoned may, and often do, move to quash subpoenas duces tecum on the ground of irrelevancy or immateriality. They will usually refer to the formal papers on file as defining the issues to which the documents called for by the subpoenas must have some relevancy. They will refer, for example, to the application or certificate of the district attorney for impaneling of the grand jury, and, if filed, to letters of the Attorney General appointing the special assistants for the particular case. For that and other reasons mentioned above, great care ought to be exercised in the preparation of those first papers.

Persons served with subpoenas, being mere witnesses-and sometimes not even that ${ }^{8 B}$-are greatly limited in the kind of attack that they may make on the grand jury proceedings. For example, in United States v. Blair, ${ }^{67}$ the Supreme Court held that a person served with a subpoena duces tecum had no standing to attack the constitutionality of the act, violation of which the grand jury was investigating.

Subpoenas duces tecum in most districts need not be signed by the district judge, although it is wise practice to lay a basis by obtaining leave of court for their issuance. It is the practice in the District of Columbia for the judges to sign personally the subpoenas duces tecum. The general rule is that the subpoenas must be reasonable as to their requirements, and specify with reasonable particularity the subjects of the required writings. In determining reasonableness the court balances con-

${ }^{60}$ Often subpoenas duces tecum contain no ad testificandum clause.

${ }^{17} 250$ U. S. 273 (1919). 
siderations on both sides as in any case where reasonableness is an issue. The most useful case, certainly from the standpoint of Government counsel, in this connection is Brown v. United States, ${ }^{88}$ where the Supreme Court expressly approved a Government subpoena duces tecum set out in the opinion. The subpoena approved there is very, very broad. It called for "All letters or copies of letters, telegrams or copies of telegrams, incoming and outgoing, passing between" a certain association and its predecessor, another association and its predecessor and another association, and the officers and agents and several members of one association, and the members of the predecessor association, including corporations, partnerships and individuals, and their respective officers and agents, "during the period from January I, I922, to June 15, I925, relating to the manufacture and sale of case goods, and particularly with reference to...." Then follows a list from (a) to ( $r$ ) of more definite subject matters but, again, in general terms, such as general meetings of the association, zone meetings of the association members, costs of manufacture, grading of various types of case goods, issuing new price lists, etc.-all very broad, general concepts. Subpoenas duces tecum for grand juries are likely not to be quashed if based on that particular subpoena approved by the Supreme Court of the United States: Nevertheless, since no other case is likely to require the same material as evidence, it is best to insert as many limiting and identifying criteria as possible. They all help in an, argument, when challenged, that the requirement is a reasonable one. ${ }^{00}$

By express provision of Section ${ }^{3} 3$ of the Clayton Act, ${ }^{70}$ subpoenas duces tecum in antitrust criminal cases run into any other district, and the limitation to a distance of I00 miles, which obtains in civil cases in the absence of express permission of the court, does not apply to criminal cases.

\section{Impounding Documents}

Some decisions indicate that inspection of subpoenaed documents by Government counsel may be made only in the presence of the grand jury itself. ${ }^{71}$ That rule has doubtless grown up in the usual small criminal cases where very few documents are furnished and there is no great practical objection to such a course. It can scarcely be the result of experience in antitrust cases where almost tons of material are sometimes subpoenaed.

It is also said to be proper practice for the documents to be taken away by the witness who brings them, after the grand jury itself is through with them. Now; obviously these two rules must be coped with in some way if Government counsel

${ }^{88} 276$ U. S. 134 (1928).

${ }^{\circ 0}$ For example, the first subpoena in the case against the American Medical Association, although closely following the Brown case, stipra note 68, certainly in substance and largely in form, was quashed because calling for all communications between certain doctors relating to certain broad subjects. U. S. v. Medical Society, 26 F. Supp. 55 (D. C. 1938). The main objection was that the requirement was unreasonable because no showing was made that the American Medical Association officials knew of the documents required. However, a new subpoena duces tecum calling for the identical material was later held valid, mainly because this time it contained a limitation that the documents required be known to any one of a long list of individuals. In re American Medical Ass'n, 26 F. Supp. 58 (D. C. 1938).

${ }^{70}$ I5 U. S. C. $\$ 23$.

${ }^{71}$ In re American Sugar Refining Co., 178 Fed. rog (S. D. N. Y., 1910), and cases cited therein. 
is to examine voluminous documents while the grand jury is sitting, and to digest them, catalogue them, and become familiar with them after the grand jury is discharged. Some arrangements for impounding these documents and for taking photostatic copies of important ones must be made. This can often be done by agreement with defense counsel, but, if he is unwilling, ample authority exists for the court, in its discretion, to enter an order impounding the documents for either or both parties. ${ }^{72}$ It has been suggested that statutory authority, if necessary, is found in the federal statute that district courts may issue all necessary writs agreeable to the usages and principles of law. ${ }^{73}$ One case ${ }^{74}$ indicates that as the basis for its decision. Another possible basis might be found in the statute permitting a district court to make rules to govern its practice. Some cases under that statute uphold such rules even when applicable only to specific, individual cases.

A number of decided cases go much further. Thus, in United States v. McHie, ${ }^{75}$ the court refused to set aside impounding orders entered after the indictment was found and before trial, impounding documents of a third party which had been obtained by unlawful seizure. In Perlman v. Firestone Tire \& Rubber Co., ${ }^{76}$ exhibits in a civil patent case belonging to Perlman were impounded for use by the district attorney in obtaining a perjury indictment against him.

Documents produced before the grand jury have been impounded in a number of the Government's antitrust cases. They were impounded in the oil cases at Madison. The orders there provided that the documents remain in the custody of the Clerk of the Court, subject to reasonable access by all interested parties. After the indictments, the defendants applied for the absolute return of the documents, but, on a showing by the Government that it needed the documents and did not want to risk their destruction, the Court ordered them released to the defendants, provided that they should be returned to the Clerk at least thirty days before trial, during those thirty days both sides to have reasonable access.

\section{Self-incrimination and Waiver of Immunity}

The Fifth Amendment guarantees against self-incrimination, but it has been held that, if a statute confers on the witness broad enough immunity from prosecution, such evidence as would otherwise be incriminating can be exacted. The federal statute ${ }^{77}$ applicable to grand jury testimony provides:

No person shall be prosecuted or be subjected to any penalty or 'forfeiture for or on account of any transaction, matter or thing concerning which he may testify or produce evidence, documentary or otherwise, in any proceeding, suit, or prosecution under Secs. $\mathrm{I}-27$, inclusive, of this chapter: Provided, That no person so testifying shall be exempt from prosecution or punishment for perjury committed in so testifying.

${ }^{72}$ See 4 Wigmore, Evidence (2d ed. I923) \$2200; Gray v. Schneider, II9 Fed. 474 (S. D. N. Y. 1902); Newcomb v. Burbank, 159 Fed. 568 (S. D. N. Y. I907).

78 U. S. C. $\$ 377$.

74 U. S. v. McHie, 196 Fed. 586 (N. D. Ill. 19ז2).

${ }^{7}$ Ibid.

${ }^{70} 244$ Fed. 304 (S. D. N. Y. I9I7), affd, 247 Ú. S. 7 (19I8).

${ }^{77} 15$ U. S. C. $\$ 32$. 
Since the broad immunity is given, the constitutional objection to self-incrimination can no longer be urged. A later amendment ${ }^{78}$ to that statute adds that "immunity shall extend only to a natural person who, in obedience to a subpoenna, gives testimony under oath or produces evidence, documentary or otherwise, under oath." Applied literally, that statute protects only those who come in obedience to subpoenas and not those who come voluntarily.

Authority seems split upon whether the immunity is conferred automatically by merely appearing and testifying under oath in obedience to a subpoena. The literal words of the statute would certainly indicate that it is granted without more. Nevertheless, some recent cases indicate that this statute is to be construed similarly to the constitutional provision and that, since a witness must make a claim for his privilege under the Constitution against giving self-incriminating evidence, he must, to obtain immunity under the statute, make a claim before testifying. ${ }^{70}$ United States $v$. Greater New York Live Poultry Chamber of Commerce holds that no immunity is given unless the witness has given incriminating evidence and has claimed privilege, or unless facts exist which may fairly be considered to be equivalent to such action. ${ }^{80}$ Here again, however, counsel may not want to risk relying upon a mere failure to make a claim, especially where the witness is a layman and his constitutional and statutory rights have not been explained to him.

It is best to avoid giving any color or basis for a controversy with a defendant about whether or not he received immunity. If he is not to be granted immunity, do not bring him before the grand jury without an express waiver for, if there is any controversy, his counsel will undoubtedly demand the transcript and may succeed in obtaining it. If he does so, the information it contains is the property not only of that particular defendant but of all the others.

A form of waiver of immunity probably need contain no words of art, but should make clear that the witness has been duly informed as to his rights.

\section{Use of Grand Tury Transcript at the Trial}

A grand jury transcript, though secret, should be of great value to the Government in the trial of an indictment. Outlined briefly below are certain purposes for which testimony of a witness befor the grand jury may be used in the Government's examination of the same witness at the trial, together with some comment on the conditions to which these uses of the transcript may be subject. The purposes are the following:

(I) To impeach a Government witness who surprises counsel by proving hostile and giving affirmative evidence for the opposition. ${ }^{8 \mathbf{I}}$

${ }^{28}$ Id. $\$ 33$.

${ }^{70}$ U. S. v. Lay Fish Co., I3 F. (2d) iz6 (S. D. N. Y. 1926); U. S. v. Greater N. Y. Live Poultry Chamber of Commerce, 33 F. (2d) ro05 (S. D. N. Y. 1929).

- ${ }^{\text {so }}$ Id. at roo6.

${ }^{81}$ Hickory v. U. S., I5r U. S. 303 (1894); Tacoma Ry. \& Power Co. v. Hays, rro Fed. 496 (C. C. A. gth, rgor); Sneed v. U. S., 298 Fed. 9 II (C. C. A. 5th, 1924); Randazzo v. U. S., 300 Fed. 794 (C. C. A. 8th, 1924); cf. Kuhn v. U. S., 24 F. (2d) 9ro (C. C. A. 9th, 1928). Perhaps the element 
(2) To impeach an opposition witness.

(3) To refresh the recollection of a witness who is truly forgetful..$^{82}$

(4) To "refresh" the recollection of a hostile or evasive witness who may be shamming forgetfulness. ${ }^{83}$

In the first case, the jury is asked to disbelieve the present testimony of the witness because inconsistent with his grand jury testimony, regardless of the truth of the latter. The witness' testimony must be shown to the opposing counsel (perhaps even if the witness admits the prior inconsistent statements) so that counsel may determine whether, in the context, the statements actually were inconsistent. ${ }^{84}$ If the witness does not admit the prior statements, the transcript, after proper authentication, should be offered in evidence.

In the second case, it is less clear that opposing counsel must be shown the transscript. If the witness had not claimed immunity before grand jury and takes the stand voluntarily at the trial, the transcript may be used to interrogate him and, affirmatively, as a confession.

In the third and fourth situations, if the transcript is shown to the witness, then it, like all documents shown the witness, must also be exhibited to his counsel. ${ }^{85}$ Where, however, the transcript is merely read to the witness it is not clear that his counsel is entitled to see it. It has been argued that such exhibition is required to prevent improper communications to witness and to permit counsel to determine whether the writing has a reasonable tendency to refresh. ${ }^{86}$ In a recent case the Government relied on cases ${ }^{87}$ holding exhibition unnecessary where writings used for refreshing purposes only were not shown to the witness. The Circuit Court of Appeals for the $7^{\text {th }}$ Circuit reversed the trial court's ruling which had sustained

of surprise is not essential. See London Guar. \& Acc. Co. v. Woelfle, 83 F. (2d) 325 (C. C. A. 8th, 1936). Cf. Sullivan v. U. S., 28 F. (2d) I47 (C. C. A. 9th, 1928).

${ }^{22}$ Hickory v. U. S., supra note 8I; Putnam v. U. S., 162 U. S. 687 (1896); Hyde v. U. S., 225 U. S. 347 (I9rI); U. S. v. Petrie, 59 F. (2d) 1005 (C. C. A. 2d, 1932).

88 London Guar. \& Acc. Co. v. Woelfle, supra note 8x; Hickory v. U. S., supra note 81; Jelke v. U. S., 255 Fed. 264 (C. C. A. 7th, 1918); Beddell v. U, S., 68 F. (2d) 776 (App. D. C. I934); Schonfeld v. U. S., 277 Fed. 934 (C. C. A. 2d, I92I); U. S. v. Freundlich, 95 F. (2d) 376 (C. C. A. 2d, 1938 ).

The application of the term "refresh" to this situation is recognized as wholly proper. Hickory v. U. S., supra note $8 \mathrm{r}$. To permit such refreshing should rest in the sound discretion of the trial court. Bosselman v. U. S., 239 Fed. 82, 85 (C. C. A. 2d, 19r7); Felder v. U. S., 9 F. (2d) 872,874 (C. C. A. 2d, 1925); DiCarlo v. U. S., 6 F. (2d) 364, 367-368 (C. C. A. 2d, 1925), cert. denied, 268 U. S. 706 (1925); U. S. v. Freundlich, supra, at 379. Resort to this practice may be limited to some extent by the policy of secrecy of grand jury proceedings. Metzler v. U. S., 64 F. (2d) 203 (C. C. A. 9th, 1933); U. S. v. Garsson, 291 Fed. 646 (S. D. N. Y. 1923); U. S. v. Violon, 173 Fed.'50I (S. D. N. Y. 1909); U. S. v. Southmayd, Fed. Cas. No. 16,36I (E. D. Wis. 1875).

842 Wigmore, Evidence (2d ed. 1923 ) $\$ \$ 753$, ro45. Wright v. Bragg, 96 Fed. 729,733 (C. C. A. 7 th, I899), cert. denied, I86 U. S. 486 (1902); Levinson v. U. S., 263 Fed. 257,258 (C. C. A. 3d, 1920); Powers v. U. S., 294 Fed. 512, 514 (C. C.. A. 5th, 1923).

${ }^{85}$ Morris v. U. S., I49 Fed. 123 (C. C. A. 5th, I907); Taylor v. U. S., I9 F. (2d) 813 (C. C. A. 8th, 1927); Little v. U. S., 93 F. (2d) 40 I (C. C. A. 8th, 1937).

${ }_{80}$ Lennon v. U. S., 20 F. (2d) $490,493-494$ (C. C. A. 8th, 1927); Arnold v. Chesebrough, 30 Fed. 145,146 (E. D. N. Y. 1887 ).

${ }^{87}$ Lennon v. U. S., supra note 86 ; Mullaney v. U. S., 82 F. (2d) 638 (C. C. A. 9th, 1936); Metzler v. U. S., stupra, note 83 . 
the Government's position.8 ${ }^{88}$ The Supreme Court has granted writs of certiorari to review this and other rulings by the Circuit Court of Appeals in this case. ${ }^{80}$

In any event care must be taken not to overdo the practice lest it be charged that an attempt is being made to put the prior inconsistent statement in evidence through the mouth of Government counsel rather than of the witness on the stand. If, in trying to improve the witness' testimony on the stand, you can prompt him to correct his testimony, well and good. But, if this attempt reaches the point of actually putting before the petit jury as affirmative evidence in the trial what the witness said before the grand jury, that, of course, is improper. ${ }^{90}$ This expedient must, therefore, be resorted to with restraint. Counsel is on reasonably safe ground where the witness admits making the prior statements by express statement or even by manifesting confusion and embarrassment. ${ }^{91}$ But where the witness blandly and categorically denies the statements, counsel should not persist in the "refreshing" process.

Confusion between the use of prior inconsistent statements to refresh testimony and their use as past recollection recorded ("canned recollection"), where no recollection exists to be revived, has led in some cases to the erroneous application to the former situation of rules appropriate only in the latter. Thus, it should not be necessary for the witness to have made or read over the transcript. ${ }^{02}$ Nor, since the transcript is not being offered in evidence, should it have to be authenticated. ${ }^{03}$ Again, it should be unnecessary that the testimony has been given contemporaeously with the event which it concerns. ${ }^{94}$ All these safeguards may be needed if the transcript is to be used as a substitute for the witness' recollection; none is called for where the transcript's only use is to stimulate that recollection. ${ }^{95}$

\section{Presentments}

Often one hears of a presentment. In some jurisdictions there are both presentments and indictments. The question is often asked: What is the distinction between the two? The confusion between them can best be resolved by a portion of Mr. Justice Field's charge to a grand jury: ${ }^{96}$

"The constitution, as you have observed, speaks of a presentment or indictment by a grand jury. The latter-the indictment-is a formal accusation made . . o of a public offense. Formerly it was the practice in all courts having jurisdiction to inquire by the in-

${ }^{88}$ U. S. v. Socony-Vacuum Oil Co., 105 F. (2d) 809 (C. C. A. 7th, 1939).

${ }^{80}$ U. S. v. Socony-Vacuum Oil Co., 60 Sup. Ct. I24 (1939).

${ }^{90}$ U. S. v. Block, 88 F. (2d) 618 (C. C. A. 2d, 1937); U. S. v. Freundlich, supra note 83.

${ }^{21}$ Such conduct is evidentiary and may be weighed against a denial. DiCarlo v. U. S., 6 F. (2d) 364 (C. C. A. 2d, 1925); Curtis v. U. S., 67 F. (2d) 942 (C. C. A. 1oth, 1933).

${ }^{\circ}$ Olmstead v. U. S., rg F. (2d) 842 (C. C. A. 9 th, 1927).

${ }^{83} \mathrm{New}$ York etc. Mining Co. v. Fraser, 130 U. S. 6II (r889); Briggs Mfg. Co. v. U. S., 30 F. (2d) 962 (D. Conn. 1929) rev'd on other grounds, U. S. v. Briggs Mfg. Co., 40 F. (2d) 425 (C. C. A. 2d, I930).

' 2 Wigmore, Evidence, \$76I. The United States Supreme Court has ruled to the contrary in Putnam v. U. S., I62 U. S. 687 (1896), a decision severcly criticized in WrGmoRE, loc. cit., stupra.

${ }^{20} 2$ WIGMORE, EVIDENCE, $\$ 758$.

${ }^{\circ 0}$ Charge to the Grand Jury, 2 Saw. $667,677-678$ (C. C: D. Cal. 1872). 
tervention of a grand jury of public offenses, amounting to the grade of felonies-and such is the practice now in many courts-for the public prosecutor to hand to the grand jury an instrument of this character-that is, a bill of an indictment in form, with a list of the witnesses to establish the offense charged. If in such case the jury found that the evidence produced justified the finding of an indictment they indorsed on the instrument 'A True Bill'; otherwise, 'Not Found,' or, 'Not a True Bill,' or the word 'Ignoramus'-we know nothing of it-from the use of which latter word the bill was sometimes said to be ignored.

"A presentment differs from an indictment in that it wants technical form, and is usually found by the grand jury upon their own knowledge, or upon the evidence before them, without having any bill from the public prosecutor. It is an informal accusation, which is generally regarded in the light of instructions upon which an indictment can be framed.

"This form of accusation has fallen in disuse since the practice has prevailed-and the practice now obtains generally-for the prosecuting officer to attend the grand jury and advise them in their investigations."

Frequently the presentment is used in connection with contempt proceedings. A contempt committed before the grand jury itself is sometimes brought to the court's attention by means of a presentment. But the use of the presentment is not very general.

Where the presentment can be regarded as informal instructions to counsel, counsel should draw up an indictment in legal form. That indictment again should be presented to the grand jury. The best practice would then require that the indictment itself be voted upon by the grand jury, but in a great many cases the grand jury votes to indict but does not vote on the particular indictment. That may be sufficient. Probably the grand jurors rarely read and deliberate upon the detailed charges of a complex indictment. An indictment, nevertheless, has to be a true bill. It has to contain the formal charge voted and it must be indorsed by the foreman as a true bill.

\section{Abuse of Process}

Suppose, after an indictment has been returned and is awaiting trial, the Government calls a grand jury to investigate the same matters, frankly and avowedly to obtain additional evidence for use in the trial of the indictment. Is that an abuse of process justifying the quashing of the subpoenas? Some lawyers when suddenly confronted with that question would say yes. But wherein is the process abused? In the first place, counsel is using an instrumentality long known to the law. It is due process. No unfair advantage is taken of anybody. The witnesses will still enjoy the same immunity from prosecution; the evidence obtained will be no less reliable. Counsel is trying to get facts, and, as has been seen, getting facts is one of the principal functions of the grand jury. Why should that function stop with the returning of an indictment? Certainly, if there is some defect in an original indictment, another grand jury can be called, the identical subject matter put before it, and it can return a superseding indictment. If this can be done to remedy a defective indictment, or one thought defective, why should it not be done to remedy 
the Government's position at the trial of a good indictment? If the Government can go on and on for months and obtain a superabundance of evidence before the return of the indictment, why should it be prevented from taking two bites instead of one, from presenting an indictment after the first week or so of the investigation if a prima facie case has been made out, and continuing the exploration of the detailed facts after that time? There is no public interest in having the Government go to trial with a partially explored case when it is found that further investigation is needed to make possible a well-prepared one.

Nevertheless, there is one decision, at least, in the federal jurisprudence which is contrary to this view. ${ }^{97}$ In that case Government counsel, having obtained an indictment in New York, went to Ohio and issued subpoenas for presentation of the same subject matter to an Ohio grand jury. Government counsel avowed frankly that one of the purposes, and perhaps the dominant purpose, was to collect evidence for the trial of the New York indictment. They did allege that there was some question as to the New York District Court's jurisdiction and, if jurisdiction failed in New York, they would want a second line of defense, to wit, an indictment in Ohio. But because the dominant motive was to get evidence for use in New York the District Court in Ohio quashed the subpoenas and dismissed the grand jury.

There are decisions opposed to this one. Judge Learned Hand in In re Kittle $e^{08}$ refused to relieve from grand jury examination a petitioner. who had been named in an existing indictment. Even on the assumption that the subject matter of inquiry and indictment were the same, Judge Hand denied the propriety of judicial interference, pointing to the autonomous position of the grand jury and its independence of the court. The court, he stated, could, if necessary, protect the defendants after indictments had been returned. A still stronger case ${ }^{89}$ arose in the Eastern District of Pennsylvania where it was clear that the testimony before the Pennsylvania grand jury was wanted by the Government for the trial of a civil case pending in New Jersey. In denying a motion to restrain the disclosure of evidence obtained in Pennsylvania, the court stated that the inquisitorial power of the grand jury should not be curtailed "except in the clearest cases." 100

The most recent case is a decision arising out of the Madison oil cases. ${ }^{101}$ In the first trial of indictments obtained in those cases, certain defendants were acquitted and others convicted. While new trials and appeals were pending, the Government instituted new grand jury proceedings in the Eastern District of Illinois and subpoenaed certain of the defendants in the first cases. These defendants petitioned for the quashing of the subpoenas and for an order restraining Government counsel from calling witnesses concerning any matter connected with the indictments pending in the Western District of Wisconsin, the ground being that the Government

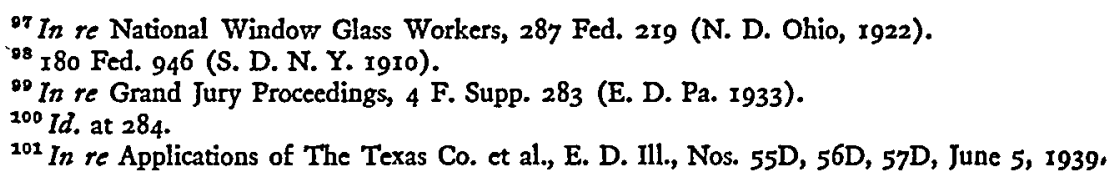


was improperly employing the processes of the court in Illinois to prepare its case against the petitioners in Wisconsin. The Government answered that, in addition to obtaining evidence which might be used in the trial of its pending indictment, it intended to investigate before the Illinois grand jury the alleged continuation of illegal practices embraced in the Wisconsin indictments and that it would seek indictments for any new violations of the antitrust laws warranted by the evidence. After an extended discussion of the tripartite nature of our Government and the historic functions of the grand jury, the court held that for it to deny to the executive department the power to present to a grand jury matters which Government counsel stated were necessary to a complete investigation and prosecution of a suspected violation of law would constitute "an usurpation of power by the court over the acts of a coordinate branch of the Government." The court added that "it is of no importance whether there are other indictments against these petitioners, or any of them, in other districts."

The circumstances of this case leave open the question whether the Government may, despite the existence of an indictment, call another grand jury to investigate the same subject matter to obtain additional facts solely for use in the trial of the existing indictment. Such a case would test the soundness of Judge Hand's view that the grand jury is "answerable only to the general body of citizens, from whom they come at random, and with whom they are again at once merged."102

${ }^{102}$ In re Kittle, supra note 98 , at 947 . 